\title{
Groundwater simulation system study on physical and climatic properties on Kuwait group aquifer
}

\author{
AlAli, Emad Hussain \\ Kuwait Institute for Scientific Research, FRD/AAD, P.O.Box 24885 Safat 13109, Kuwait
}

Email address:

eali@kisr.edu.kw

\section{To cite this article:}

AlAli, Emad Hussain. Groundwater Simulation System Study on Physical and Climatic properties on Kuwait Group Aquifer. International Journal of Environmental Monitoring and Analysis. Vol. 1, No. 5, 2013, pp. 258-272. doi: 10.11648/j.ijema.20130105.21

\begin{abstract}
In Kuwait natural resources of fresh water are very limited. Kuwait is situated in an arid coastal region characterized by high temperatures, low humidity, sparse precipitation rates, and high evaporation and evapotranspiration rates with no rivers or lakes. Therefore, Kuwait has always relied on other sources to secure freshwater to meet its growing demands. The aim of this study was to design a conceptual system to provide a sustainable water source at a feasible cost. The conceptual design system was developed to address the problem of water scarcity and sustainability in general, and specifically to represent the Kuwaiti water quality and quantity limitation problem. The conceptual design system consists primarily of utilizing brackish groundwater in conjunction with treated wastewater augmentation and a reverse osmosis unit for plant production, the simulation was chosen to represent the quasi-Kuwaiti environment data.The study considered two types of simulation models for the conceptual design system approach. These models are the lump model approach and the areal distribution model approach. The lump model approach was carried out through the construction of a simplified model approach utilizing the Visual Basic model. On the other hand, the areal distribution model approach was carried out through the utilization of the Visual MODFLOW and MT3D simulation model approach. This paper present a part of the study that directed to test the physical and climatic performance, and the durability of the conceptual design system, Visual basic, lump, model simulation approach was simulated for different ranges of hydrologic, hydrogeologic, and climatic parameters to determine the total power and treated wastewater consumption. From the performance test results, the increase in evapotranspiration had the highest increase effect on the system total power consumption per unit area and the highest increase effect on the treated wastewater consumption per unit area. On the other hand, the increase in the aquifer porosity had the least increase effect on both the total power consumption and the treated wastewater consumption by the system. In contrast, the hydraulic conductivity increase had no direct effect on either the total power consumption or on the treated wastewater consumption per unit area.
\end{abstract}

Keywords: Groundwater, Groundwater Model, Treated Wastewater Injection, Reverse Osmosis, Evapotranspiration, Porosity, Hydraulic Conductivity, Water Head Table, Groundwater Salt Concentration

\section{Introduction}

Water scarcity is the predominant issue in the arid and semi arid countries. In particular, most Middle East countries and the Gulf Cooperation Council (GCC) countries, in particular, are characterized by extremely arid climate and limited surface water supplies. The major water resource for these countries is groundwater $(91 \%)$ and desalination of seawater (7.2\%). The lack of freshwater resources in these regions constitutes a major deterrent to their sustainable development.

In Kuwait, one of the GCC countries, natural resources of fresh water are very limited. Kuwaitis situated in an arid coastal region characterized by high temperatures, low humidity, sparse precipitation rates, and high evaporation and evapotranspiration rates with no rivers or lakes. Therefore, Kuwait has always relied on other secure freshwater to meet its growing demands. The water supply in Kuwait can be obtained from three main sources: brackish groundwater, water reuse (treated wastewater), and seawater desalination.

Brackish groundwater exists in reasonable quantities. During 1999, the daily production of brackish groundwater was around 400 million imperial gallons per day (MIGD), which is almost 3 times the annual groundwater inflow(MEW, 2000).Thus, the production of brackish groundwater is exhausting the one and only vital natural 
water source.

In Kuwait, treated wastewater is an almost unused water source. Urban wastewateris collected, treated and returned to the sea; limited quantities are utilized forlandscaping purposes. In Kuwait, wastewater effluent is treated to a secondary or tertiary level. The relatively low salinity of the treated wastewater $(1000 \mathrm{mg} / \mathrm{l})$ compared with brackish water of $4000-10000 \mathrm{mg} / \mathrm{l}$ makes it a potentially excellent source of good quality water. Moreover, over 100 million imperial gallons per day (MIGD) of treated wastewater production in Kuwaitwill have a great potential to supplement/ replace the brackish water supplies.

\section{Study Area}

Modeling and simulation

\section{Study Cite}

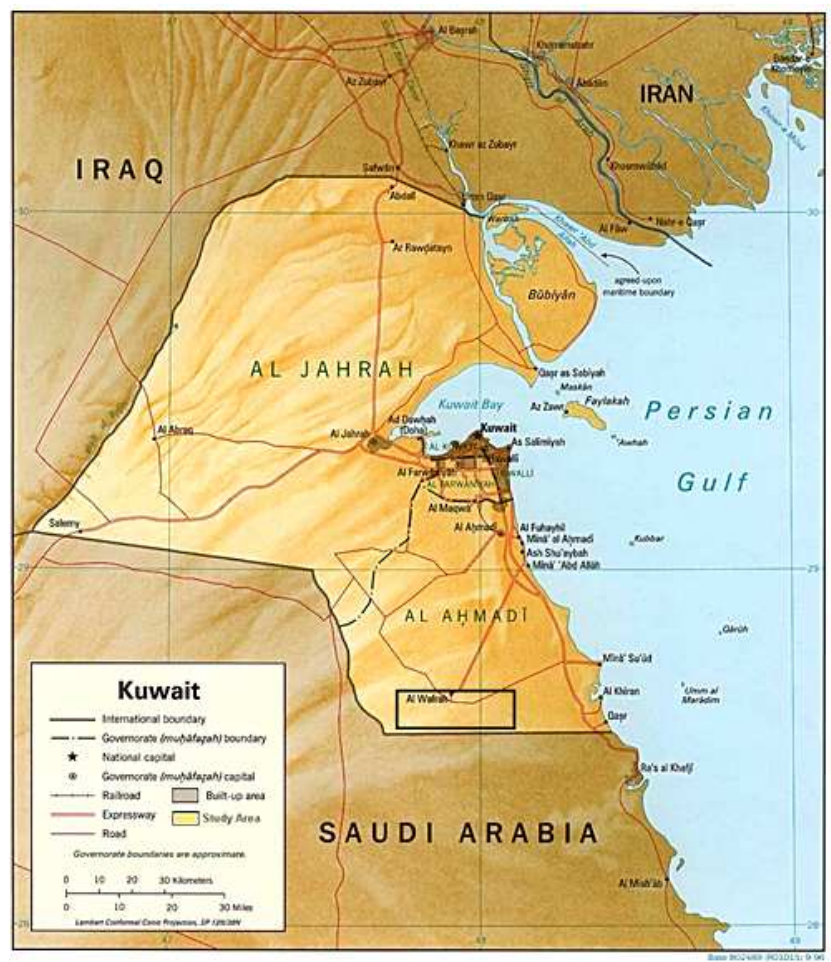

Figure 1. Wafra area (Study area) location map, Kuwait.

The Wafra area is located in Kuwait near the southern border with Saudi Arabia between latitude $28^{\circ} 30^{\prime}$ and 28 $45^{\prime} \mathrm{N}$ and longitudes $47^{\circ} 45^{\prime}$ and $48^{\circ} 15^{\prime} \mathrm{E}$, (Figure 1). Wafra is generally a flat area, sloping very gently from west to east. Rainfall is restricted to winter and early spring (October-May), with a mean annual rainfall of $105 \mathrm{~mm}$ with great variability from one year to another and from one location to another. The average temperature ranges between $7{ }^{\circ} \mathrm{C}$ in January and $39.3{ }^{\circ} \mathrm{C}$ in July. The maximum temperature ranges between $14.8^{\circ} \mathrm{C}$ in January and $47.3{ }^{\circ} \mathrm{C}$ in July. The minimum temperature ranges between $2{ }^{\circ} \mathrm{C}$ in
January and $31.5^{\circ} \mathrm{C}$ in July. Relative humidity is highest in January (maximum $84 \%$ and minimum $45 \%$ ) and lowest in June (maximum $40 \%$ and minimum $13 \%$ ). The evaporation rate is very high and variable with a daily mean of $16.6 \mathrm{~mm} / \mathrm{d}$. It reaches $31 \mathrm{~mm} / \mathrm{d}$ in summer and decreases to $5.2 \mathrm{~mm} / \mathrm{d}$ in winter. Winds blow from the northwest and, to a lesser extent, from the southeast. The dray and hot northwestern winds that prevail in the early summer are mostly associated with dust storms and become particularly frequent in June and July.

\section{Method}

The purpose of this paper is to study the physical and climatic properties of the general conceptual design system while using the lump model simulation. This paper extracted a part of an integrated research which mainly aimed to study the durability and feasibility of a conceptual design system of implementing a treated wastewater recharge technique and R.O. unit system for water sustainability.The simulation will calculate, using the Visual Basic model, the overall steady state groundwater heads, salt concentrations (by way of uniform mixing scheme), steady state drawdown, and total operation power requirements, within the unconfined saturated aquifer The lump model for the general conception design system was designed to calculate the overall the treated wastewater injected and the system total operation power requirements, within the unconfined saturated aquifer, Figure 2.The simulation of the general conceptual design system will be executed while using a lump simulation model approach. To test the physical and climatic performance of the general conceptual design system, the general conceptual design system will be studied for a range of input data for different variable inputs over a 40 -year simulation period. The order of executing the lump model simulation will be governed by the following set of governing equations.

- $\quad$ Root (Vadose) Zone Governing Equations

- Reverse Osmosis (R.O.) System Governing Equations

- Groundwater Zone Governing Equations

- $\quad$ Field Area Estimation Governing Equations

The study of the conceptual design system will be executed by implementing different ranges of hydrologic, hydrogeologic, and climatic parameters, as follow:

- Actual Crop Evapotranspiration, $E T_{c}$

- $\quad$ Root Zone Salt Concentration Tolerance, $C_{R Z}$

- $\quad$ Treated Wastewater Salt Concentration, $C_{i n j}$

- $\quad$ Porosity, $\Phi$

- $\quad$ Hydraulic Conductivity, $K$

- Initial Groundwater Table Hydraulic Head Elevation, $h_{o}$

- Initial Groundwater Salt Concentration, $\left(C_{g . w}\right)^{t-1}$ 


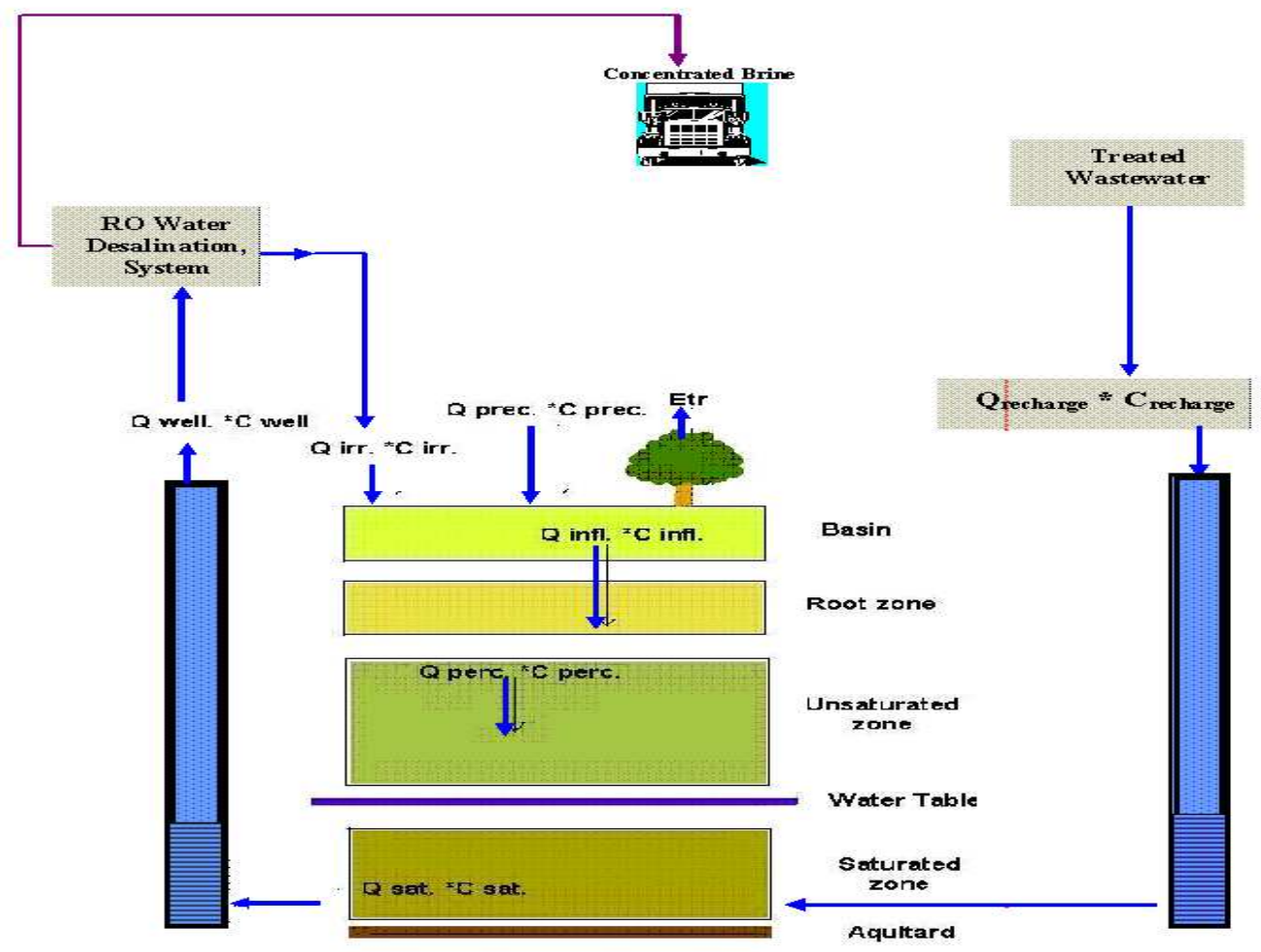

Figure 2. Conceptual design system of implementing a treated wastewater recharge technique and R.O. unit system for water sustainability.

Table 1. Groundwater assumed input data variables for all simulations.

\begin{tabular}{|c|c|c|}
\hline Variable & Value or Type & Remarks \\
\hline Aquifer Type & Unconfined Aquifer & \\
\hline Aquifer Thickness & $60(\mathrm{~m})$ & \\
\hline$r_{o}$ & $1500(\mathrm{~m})$ & Intercept of distance drawdown line with zero drawdown axis. \\
\hline$r_{w}$ & $0.5(\mathrm{~m})$ & Pumping well radius. \\
\hline Well Penetration & $60(\mathrm{~m})$ & Fully penetrated well \\
\hline Maximum Lift & $55(\mathrm{~m})$ & \\
\hline$h_{w(\min )}$ & $5(\mathrm{~m})$ & $\begin{array}{l}\text { Min. allowable hydraulic water at the pump well, for max. drawdown. (min. } \\
\text { saturated thickness) }\end{array}$ \\
\hline Well pump efficiency $\left(\eta_{\text {well }}\right)$ & $75(\%)$ & Average electrical well pump efficiency $50-80 \%$, \\
\hline
\end{tabular}

\subsection{Analysis and Discussion}

\subsubsection{Actual Crop Evapotranspiration, $\boldsymbol{E T}_{\boldsymbol{c}}$}

Actual crop evapotranspiration, $E T_{c}$, is one of the main variable input data in the simulation, as it corresponds to the amount of water lost to the ambient due to sensible and latent heat in general. Actual crop evapotranspiration data ranges $(1 \mathrm{~m} / \mathrm{season}-2 \mathrm{~m} / \mathrm{season})$ were chosen to cope with and represent the semi-dry and dry climate conditions(Table 2).

From Figures 3 and 4, it is obvious that as the actual evapotranspiration increases the higher the total power required by the system and the higher the amount of treated wastewater required to be injected into the groundwater zone. As the crop actual 
Table 2. Test performance of the general conceptual model by perturbing actual cropevapotranspiration, ET, values while keeping all other variables constant.

\begin{tabular}{|c|c|c|c|c|c|c|c|c|}
\hline Run No. & $\begin{array}{c}\mathbf{E T}_{\mathbf{c}} \\
(\mathbf{m} / \text { season) }\end{array}$ & $\begin{array}{l}\mathbf{E T}_{\mathrm{c}(\max )} \\
\text { (m/day) }\end{array}$ & $\begin{array}{c}\mathrm{C}_{\mathrm{RZ}} \\
(\mathrm{mg} / \mathrm{l})\end{array}$ & $\begin{array}{c}\mathrm{C}_{\mathrm{inj}} \\
(\mathrm{mg} / \mathrm{l})\end{array}$ & $\begin{array}{c}\Phi \\
\left(\mathrm{m}^{3} / \mathrm{m}^{3}\right)\end{array}$ & $\underset{\text { (m/day) }}{K}$ & $\begin{array}{c}\mathbf{h}_{\mathbf{0}} \\
(\mathbf{m})\end{array}$ & $\begin{array}{c}\left(\mathrm{C}_{\text {g.w. }}\right)^{\mathrm{t}-1} \\
(\mathrm{mg} / \mathrm{l})\end{array}$ \\
\hline 1 & 1.00 & 0.015 & 2000 & 1000 & 0.3 & 5 & 35 & 6000 \\
\hline 2 & 1.25 & 0.015 & 2000 & 1000 & 0.3 & 5 & 35 & 6000 \\
\hline 3 & 1.50 & 0.015 & 2000 & 1000 & 0.3 & 5 & 35 & 6000 \\
\hline 4 & 1.75 & 0.015 & 2000 & 1000 & 0.3 & 5 & 35 & 6000 \\
\hline 5 & 2.00 & 0.015 & 2000 & 1000 & 0.3 & 5 & 35 & 6000 \\
\hline
\end{tabular}

evapotranspiration increases the crop water requirement will increase. Thus, irrigation water demand will increase to meet this increase in the crop actual evapotranspiration. Moreover, to meet this increase in the irrigation water demand, a larger groundwater amount must be pumped and fed to the reverse osmosis unit to cope with the irrigation water requirement increases. In addition, the higher the pumped groundwater requirement the higher the power consumption will be used by the pump, therefore,to prevent the groundwater from mining, the higher the treated wastewater injection rate into the groundwater zone required to compensate for the higher water demand by the system (Figure 4).

\subsubsection{Root Zone Salt Concentration Tolerance, $C_{R Z}$}

Root zone salt concentration tolerance, $\boldsymbol{C}_{\boldsymbol{R} Z}$, is one of the decision variable input data in the simulation, as it symbolizes the maximum root salt concentration tolerance for a crop without a reduction in the yield. Root zone salt concentration tolerance data ranges $(1000 \mathrm{mg} / \mathrm{l}-2000 \mathrm{mg} / \mathrm{l})$ were chosen to cope with and characterize the wide varieties of plant root salt concentration tolerances (Table 4).

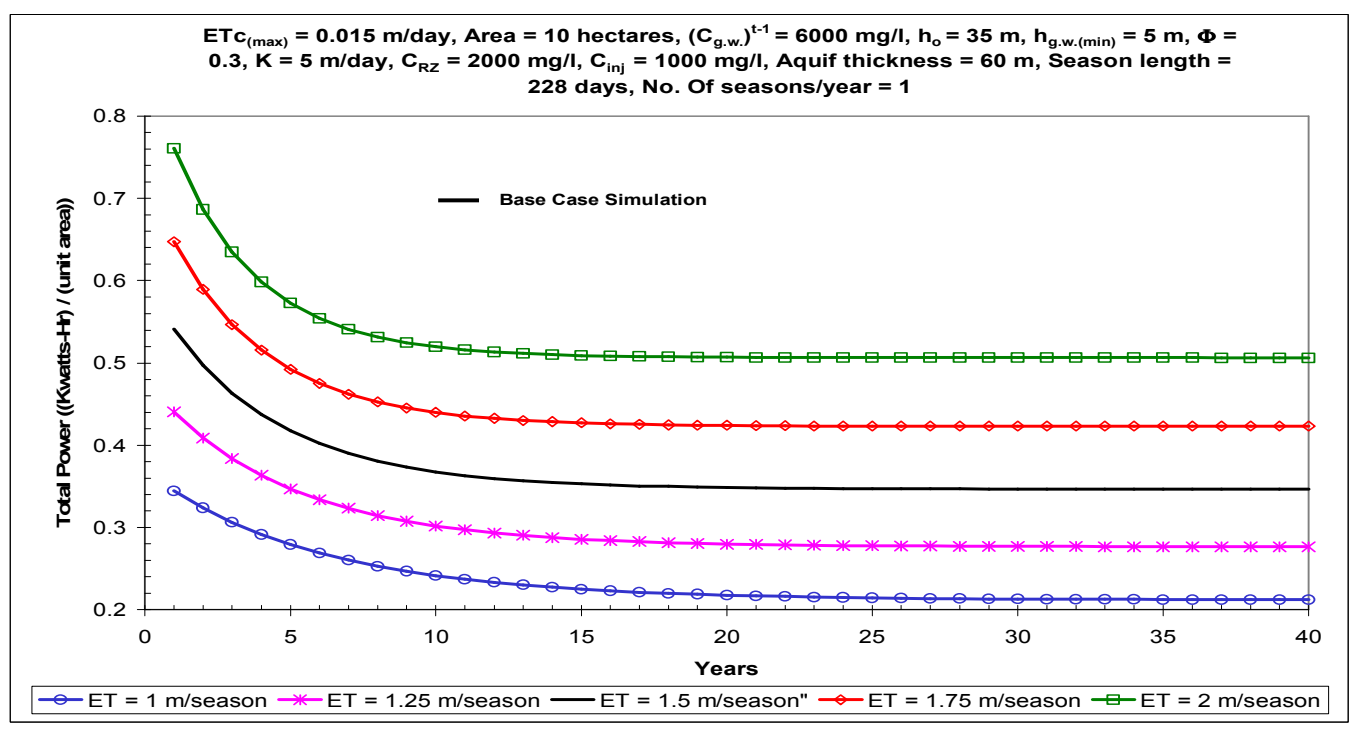

Figure 3. Total power required by the system for ranges of different actual crop evapotranspiration, ET , input values vs. simulation period.

From Figures 5 and 6 , it is obvious that as the root zone salt concentration tolerance decreases the higher the total power required by the system, and the higher amount of treated wastewater required to be injected into the groundwater zone. As the root zone salt concentration tolerance decreases the crop water requirement will increase to flush the excess salts from the root zone and to keep the salt concentration within the desirable root zone salt concentration tolerance level, thus, preventing crop yield reduction. Therefore, irrigation water demand will increase to meet this decrease in the root zone salt concentration tolerance. Moreover, to meet this increase in the irrigation water demand, a larger groundwater amount must be pumped and fed to the reverse osmosis unit to cope with the irrigation water requirement increases. Therefore, the higher the pumped groundwater amount required to be fed to the reverse osmosis unit the higher the amount of water needed to be desalinated and the more power will be consumed by the reverse osmosis unit. In addition, the higher the pumped groundwater requirement the higher the power consumption will be used by the pump.

To cope with the increase in irrigation water demand, this leads to an increase in pumped groundwater, and to prevent groundwater from mining, the more treated wastewater injection rate into the groundwater zone is required to compensate for the higher water demand by the system (Figure 6). 


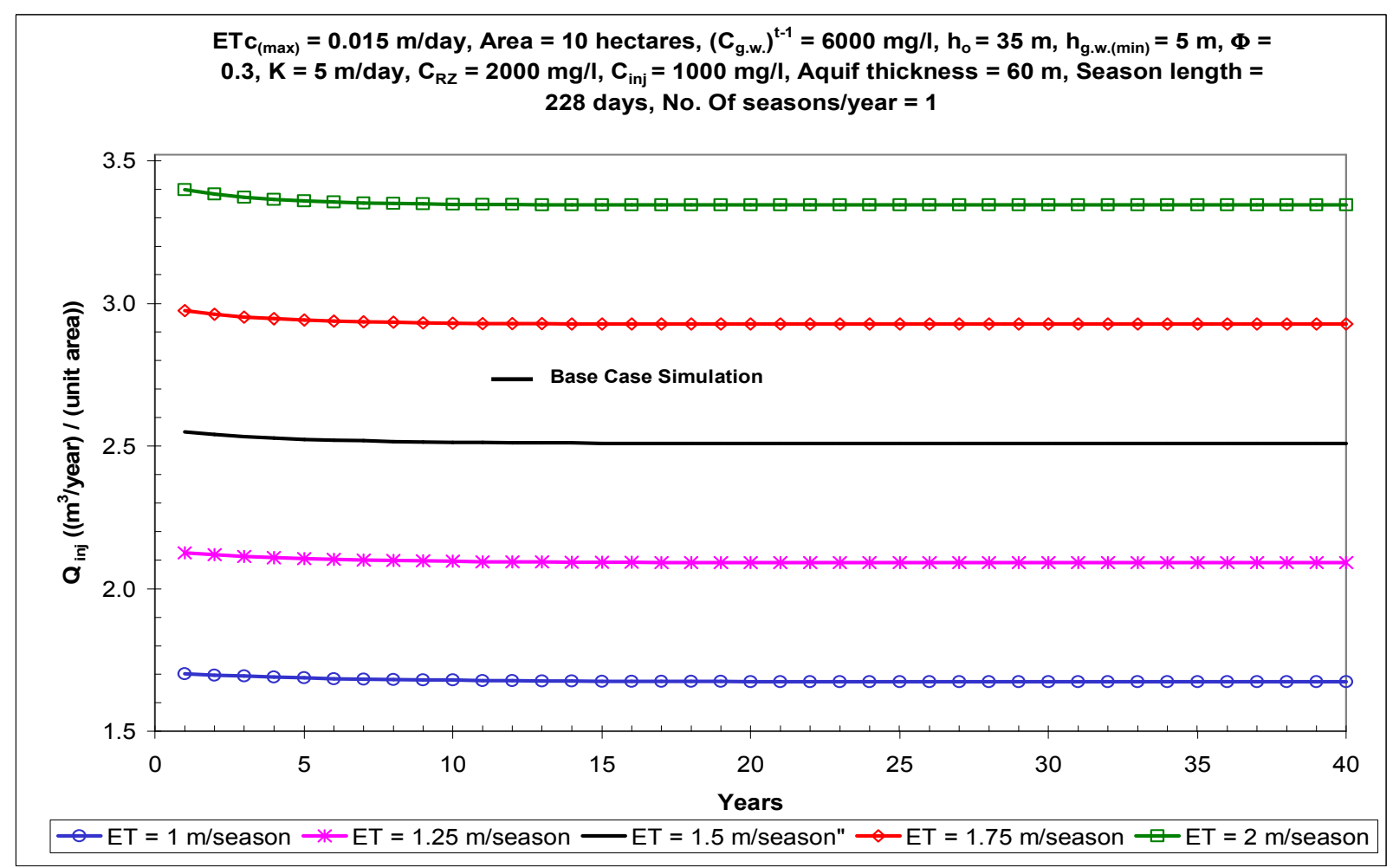

Figure 4. Amount of treated wastewater injected into the native groundwater for ranges of different actual crop evapotranspiration, ET, input values vs. simulation period.

Table 3. Percent increase in the sum of the total power consumption and the sum of the treated wastewater injection as the actual evapotranspiration increases.

\begin{tabular}{|c|c|c|c|c|}
\hline \multicolumn{2}{|c|}{$E T_{c}$ Changes (m/season) } & \multirow{2}{*}{$\%$ Change (increase) in $E T_{c}$} & \multirow{2}{*}{$\begin{array}{l}\% \text { Change } \\
\text { (increase) in the Sum of the } \\
\text { Total Power per Unit Area }\end{array}$} & \multirow{2}{*}{$\begin{array}{l}\% \text { Change (increase) } \\
\text { in the Sum of the Injected Treated } \\
\text { Wastewater per Unit Area }\end{array}$} \\
\hline From & To & & & \\
\hline 1 & 1.50 & 33.33 & 36.69 & 33.27 \\
\hline 1.25 & 1.50 & 16.67 & 19.09 & 16.64 \\
\hline 1.50 & 1.75 & 14.29 & 17.19 & 14.26 \\
\hline 1.50 & 2.00 & 25.00 & 30.27 & 24.97 \\
\hline
\end{tabular}

Table 4.Test the performance of the general conceptual model by perturbing root zone salt concentration tolerance values, $C_{R Z}$, while keeping all other variables constant.

\begin{tabular}{|c|c|c|c|c|c|c|c|c|}
\hline Run No. & $\begin{array}{l}E T_{c} \\
(m / \text { season })\end{array}$ & $\begin{array}{l}E T_{c(\max )} \\
(\boldsymbol{m} / \text { day })\end{array}$ & $\begin{array}{l}C_{R Z} \\
(m g / l)\end{array}$ & $\begin{array}{l}C_{i n j} \\
(m g / l)\end{array}$ & $\begin{array}{l}\Phi \\
\left(m^{3} / m^{3}\right)\end{array}$ & $\begin{array}{l}K \\
(m / \text { day })\end{array}$ & $\begin{array}{l}h_{o} \\
(m)\end{array}$ & $\begin{array}{l}\left(C_{g, w}\right)^{t-1} \\
(m g / l)\end{array}$ \\
\hline 1 & 1.50 & 0.015 & 1000 & 1000 & 0.3 & 5 & 35 & 6000 \\
\hline 2 & 1.50 & 0.015 & 1250 & 1000 & 0.3 & 5 & 35 & 6000 \\
\hline 3 & 1.50 & 0.015 & 1500 & 1000 & 0.3 & 5 & 35 & 6000 \\
\hline 4 & 1.50 & 0.015 & 1750 & 1000 & 0.3 & 5 & 35 & 6000 \\
\hline 5 & 1.50 & 0.015 & 2000 & 1000 & 0.3 & 5 & 35 & 6000 \\
\hline
\end{tabular}




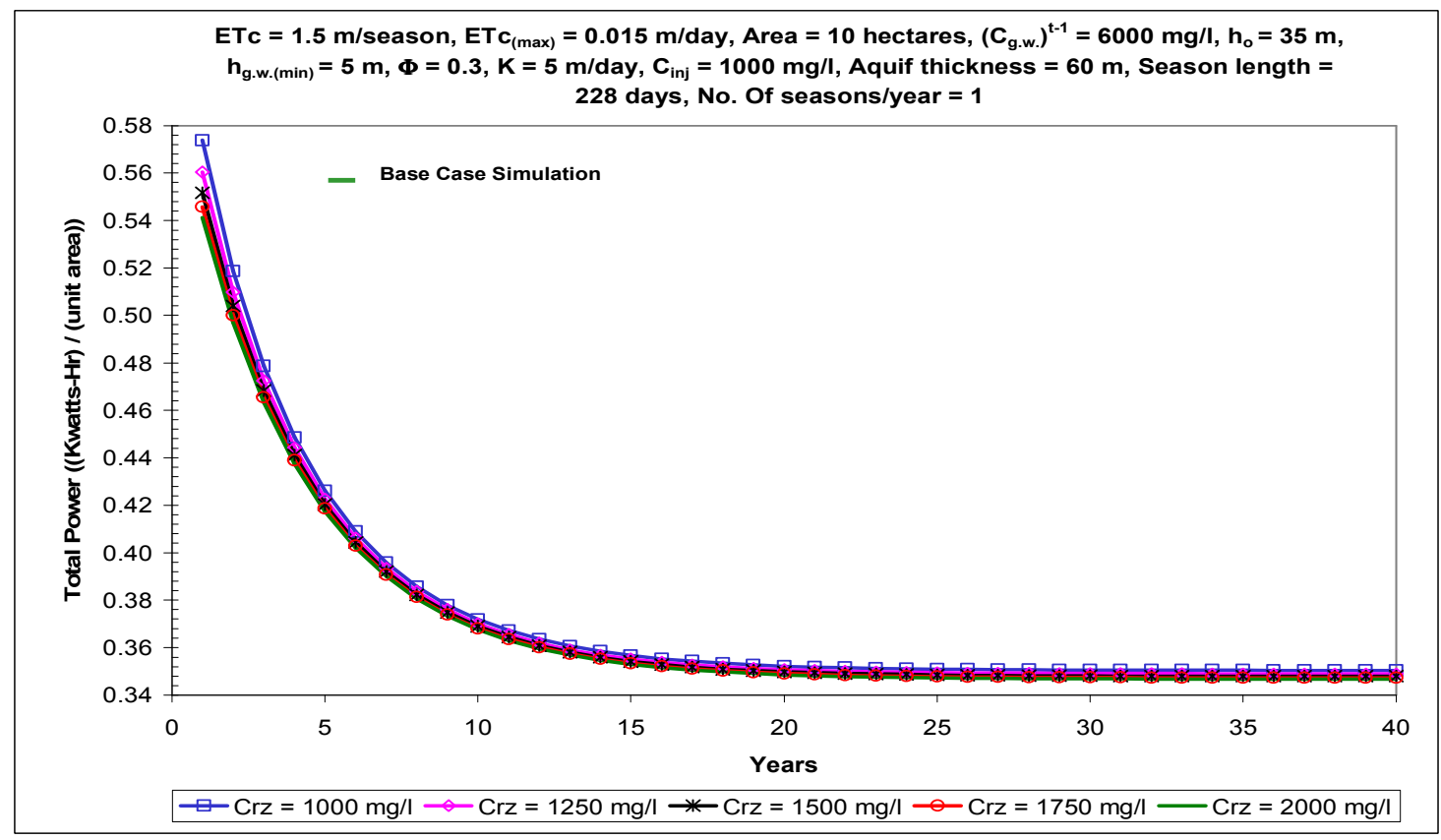

Figure 5. Total power required by the system for ranges of different root zone salt concentration tolerances, $C_{R Z}$ input values vs. simulation period.

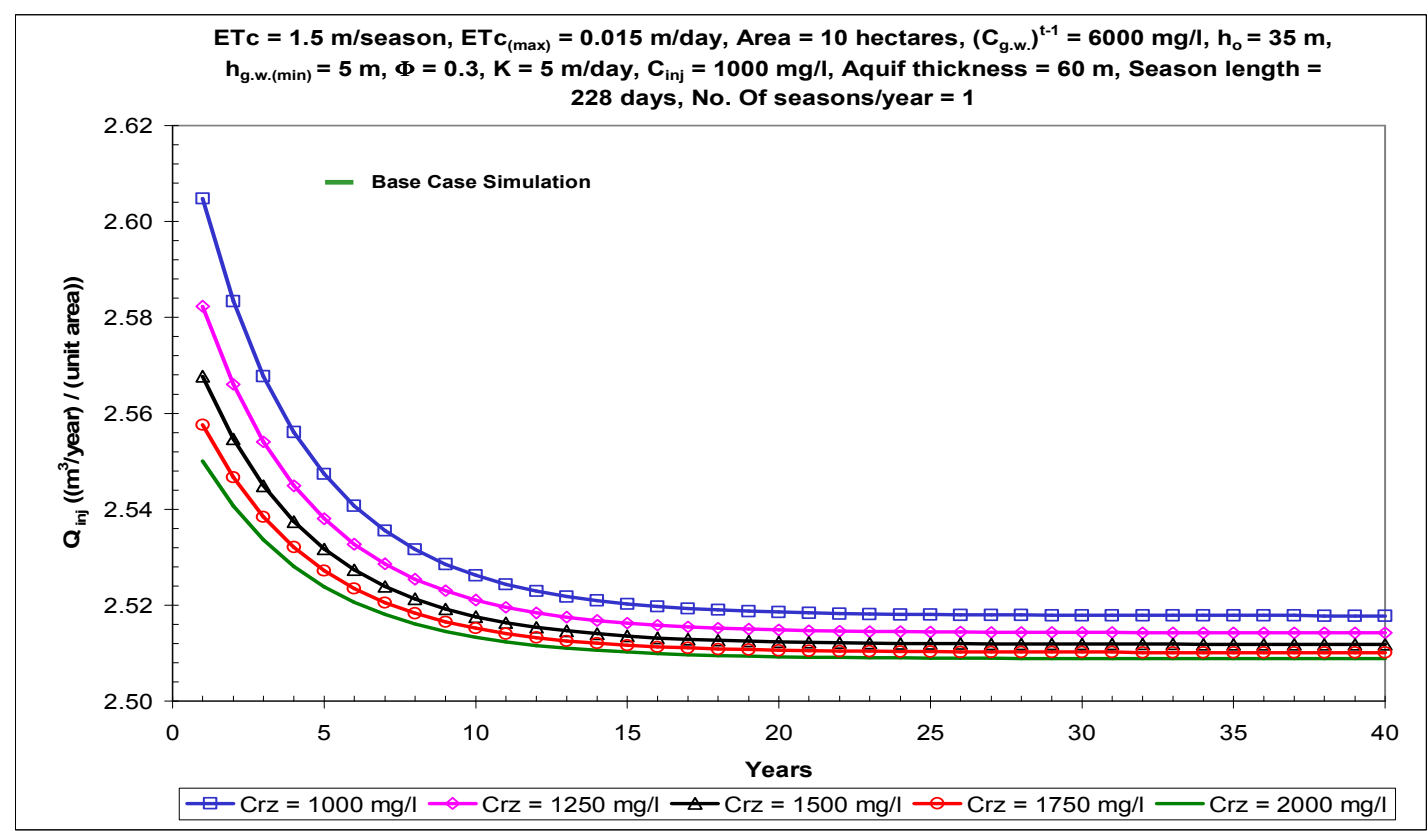

Figure 6. Amount of treated wastewater injected into the native groundwater for ranges of different root zone salt concentration tolerances, $C_{R Z}$ input values vs. simulation period.

\subsubsection{Treated Wastewater Salt Concentration, $C_{i n j}$}

Treated wastewater salt concentration, $\boldsymbol{C}_{\boldsymbol{i n j}}$, is of crucial variable input data in the simulation, because it will control the amount of added salt concentration to the groundwater in the form of injection. Treated wastewater salt concentration data ranges $(1000 \mathrm{mg} / \mathrm{l}-2000 \mathrm{mg} / \mathrm{l})$ were chosen to deal with and illustrate the range of salt concentration within most treated wastewater effluent available after tertiary or secondary treatment level (Table 6).
From Figures 7 and 8, it is obvious that as the injected treated wastewater salt concentration increases the higher the total power required by the system and the higher the amount of treated wastewater required to be injected into the groundwater zone. As the injected treated wastewater salt concentration increases, the groundwater salt concentration enhancement will be retarded. Thus, the pumped groundwater salt concentration will be relatively higher. Due to the increase in the pumped groundwater salt concentration, the feed water to the reverse 
Table 5. Percent increase in the sum of the total power consumption and the sum of the treated wastewater injection as the root zone salt concentration tolerances decreases.

\begin{tabular}{lllll}
\hline $\boldsymbol{C}_{\boldsymbol{R} Z}$ Changes (mg / $)$ & \% Change & $\begin{array}{l}\text { \% Change } \\
\text { (increase) in the Sum of the Total } \\
\text { Prom }\end{array}$ & To & $\begin{array}{l}\text { \% Change (increase) } \\
\text { in the Sum of the Injected Treated } \\
\text { Wastewater per Unit Area }\end{array}$ \\
\hline 2000 & 1000 & 50.00 & 1.47 & 0.54 \\
\hline 2000 & 1250 & 37.50 & 0.87 & 0.33 \\
\hline 2000 & 1500 & 25.00 & 0.47 & 0.18 \\
\hline 2000 & 1750 & 0.20 & 0.08 \\
\hline
\end{tabular}

osmosis unit will be at a relatively higher salt concentration. Thus, the water permeate from the reverse osmosis unit will be at a higher concentration, too. Therefore, the more permeate water is required to cope with the irrigation efficiency. Hence, irrigation water demand will increase to meet this increase in the injected treated wastewater salt concentration. Moreover, to meet this increase in the irrigation water demand, a larger groundwater amount must be pumped and fed to the reverse osmosis unit to cope with the irrigation water requirement increases. Therefore, the higher the pumped groundwater amount required to be fed to the reverse osmosis unit the higher the amount of water needed to be desalinated and the more power will be consumed by the

Table6. Test the performance of the general conceptual model by perturbing wastewater salt concentration values, $C_{i n j}$, while keeping all other variables constant.

\begin{tabular}{|c|c|c|c|c|c|c|c|c|}
\hline Run No. & $\begin{array}{l}E T_{c} \\
(\mathrm{~m} / \mathrm{season})\end{array}$ & $\begin{array}{l}E T_{c(\max )} \\
(\boldsymbol{m} / \text { day })\end{array}$ & $\begin{array}{l}C_{R Z} \\
(m g / l)\end{array}$ & $\begin{array}{l}C_{i n j} \\
(m g / l)\end{array}$ & $\begin{array}{l}\Phi \\
\left(m^{3} / m^{3}\right)\end{array}$ & $\begin{array}{l}K \\
\text { (m/day) }\end{array}$ & $\begin{array}{l}h_{o} \\
(m)\end{array}$ & $\begin{array}{l}\left(C_{g . w}\right)^{t-1} \\
(\mathrm{mg} / \mathrm{l})\end{array}$ \\
\hline 1 & 1.50 & 0.015 & 2000 & 1000 & 0.3 & 5 & 35 & 6000 \\
\hline 2 & 1.50 & 0.015 & 2000 & 1250 & 0.3 & 5 & 35 & 6000 \\
\hline 3 & 1.50 & 0.015 & 2000 & 1500 & 0.3 & 5 & 35 & 6000 \\
\hline 4 & 1.50 & 0.015 & 2000 & 1750 & 0.3 & 5 & 35 & 6000 \\
\hline 5 & 1.50 & 0.015 & 2000 & 2000 & 0.3 & 5 & 35 & 6000 \\
\hline
\end{tabular}

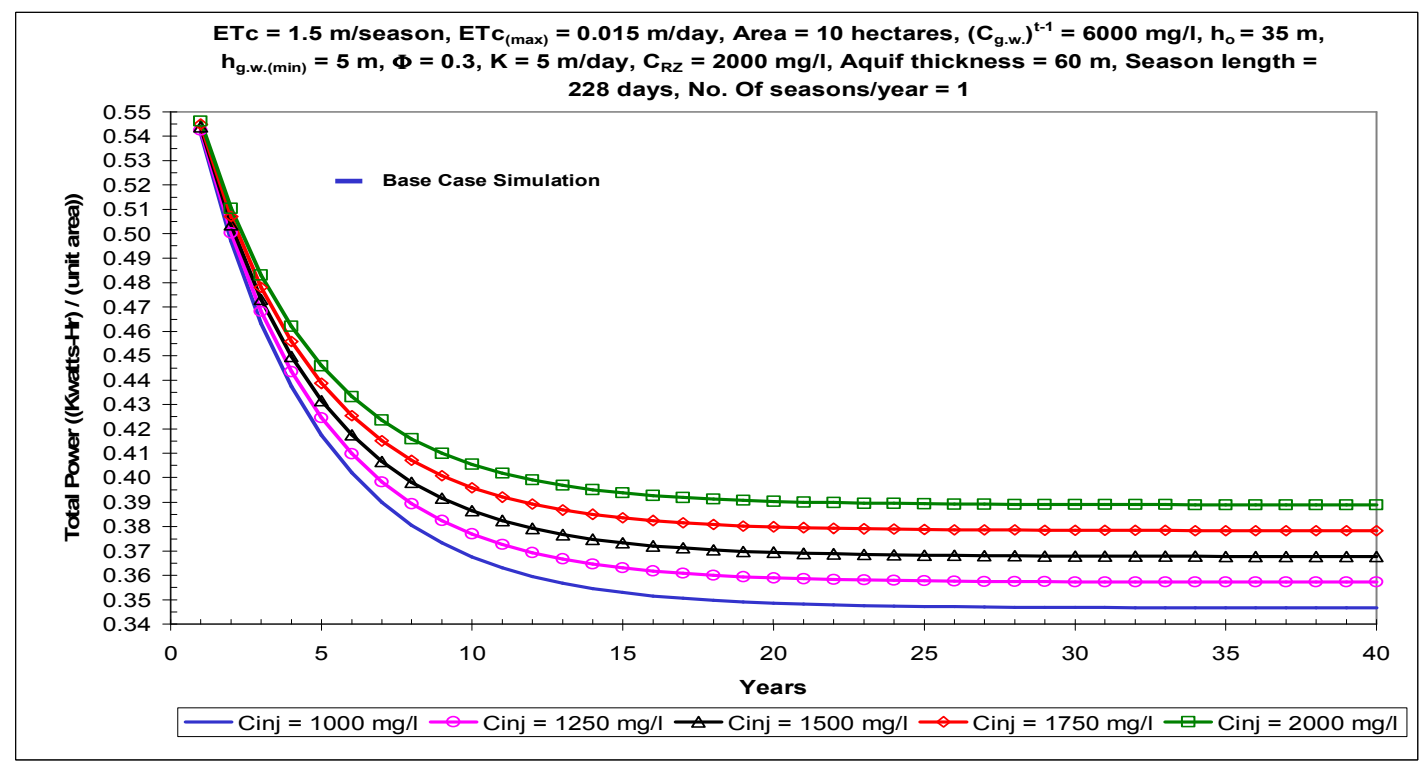

Figure 7. Total power required by the system for ranges of different treated wastewater salt concentrations, $C_{i n j}$ input values vs. simulation period. 
reverse osmosis unit. In addition, the higher the pumped groundwater requirement the higher the power consumption will be used by thepump. Thus, this leads to an increase in pumped groundwater, and to prevent groundwater from mining, the more treated wastewater injection rate into thegroundwater zone required to compensate for the higher water demand by the system.

\subsubsection{Porosity, $\Phi$}

Porosity, $\Phi$, is of fundamental importance to groundwater variable input data in the simulation, because it serves as water conduits. Porosity data ranges $(0.3-0.45)$ were chosen to cope with and distinguish wide varieties of soil type (Table 8).

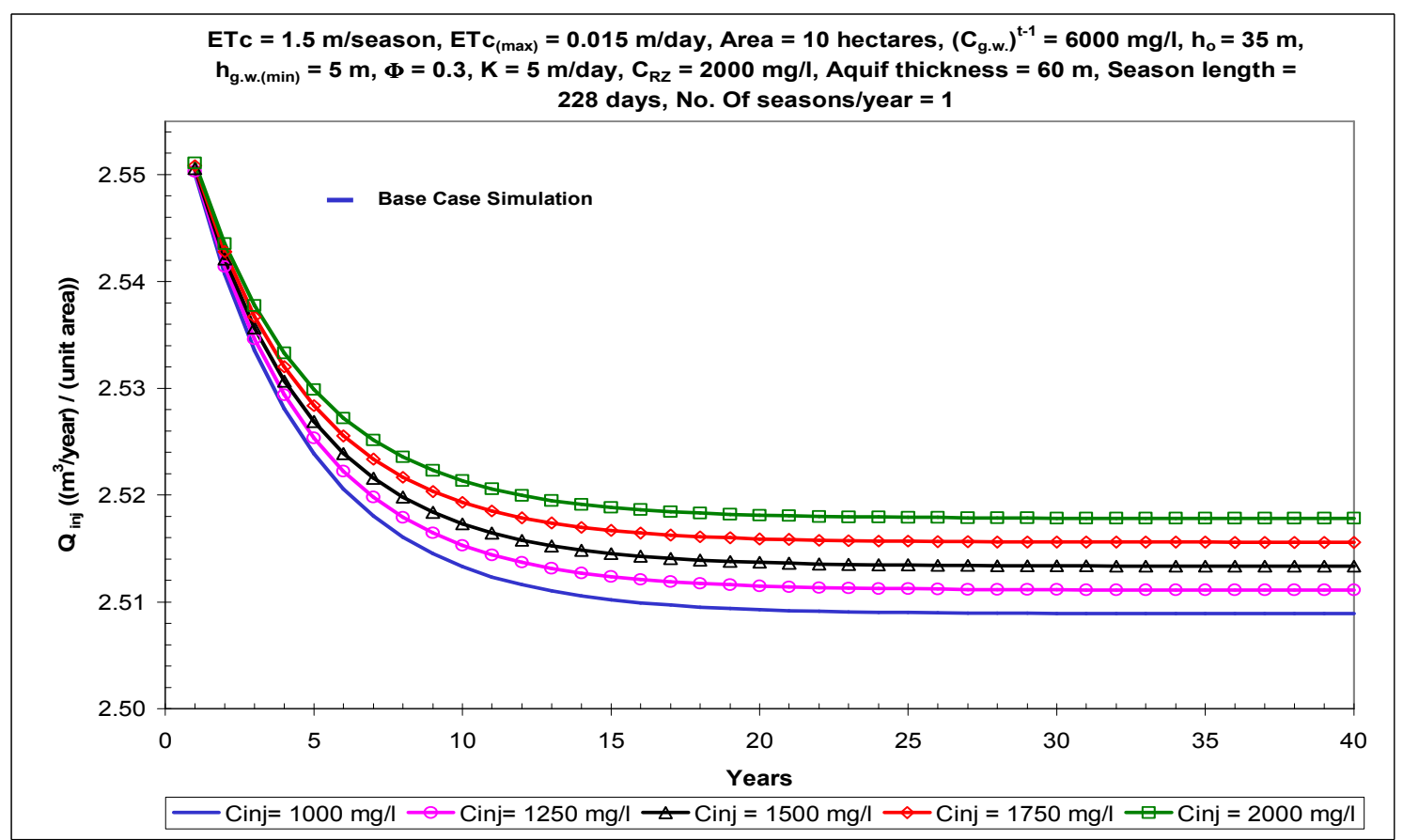

Figure 8. Amount of treated wastewater injected into the native groundwater for ranges of different treated wastewater salt concentrations, $C_{\text {inj }}$, input values vs. simulation period.

From Figures 9 and 10, it is obvious that as the porosity increases the higher the total power required by the system and the higher the amount of treated wastewater required to be injected into the groundwater. As the porosity increases, the initial volume of groundwater will increase. Thus, the initial salt mass quantity of the groundwater willincrease. Moreover, due to larger initial groundwater volume, the enhancement of the salt concentration of the groundwater will be delayed compared with smaller porosity (where the groundwater volume is less) as the simulation progresses. Thus, the pumped groundwater initial salt concentration will be relatively higher as the initial groundwater volume increases, due to the increase in porosity. Thus, the feed water to the reverse osmosis unit will be at a relatively higher salt concentration. Hence, the water permeate from the reverse osmosis unit will be at a higher concentration, too. Therefore, the more permeate water is required (to be used as irrigation water) to cope with the irrigation

Table 7. Percent increase in the sum of the total power consumption and the sum of the treated wastewater injection as the treated wastewater salt concentration increases efficiency.

\begin{tabular}{|c|c|c|c|c|}
\hline$C_{i n j} \mathrm{Ch}$ & To & $\begin{array}{l}\text { \% Change (increase) in } \\
C_{i n j}\end{array}$ & $\begin{array}{l}\text { \% Change } \\
\text { (increase) in the Sum of } \\
\text { the Total Power per } \\
\text { Unit Area }\end{array}$ & $\begin{array}{l}\text { \% Change (increase) } \\
\text { in the Sum of the Injected Treated } \\
\text { Wastewater per Unit Area }\end{array}$ \\
\hline 1000 & 1250 & 20.00 & 2.45 & 0.08 \\
\hline 1000 & 1500 & 33.33 & 4.84 & 0.16 \\
\hline 1000 & 1750 & 42.86 & 7.12 & 0.24 \\
\hline 1000 & 2000 & 50.00 & 9.29 & 0.32 \\
\hline
\end{tabular}


Hence, irrigation water demand will increase to meet this increase in the porosity. Therefore, a larger groundwater amount must be pumped and fed to the reverse osmosis unit to cope with the irrigation water requirement increases. Hence, the higher the pumped groundwater amount required to be fed to the reverse osmosis unit the higher the amount of water needed to be desalinated and the more power will be consumed bythe reverse osmosis unit. In addition, the higher the pumped groundwater requirement the higher the power consumption will be excreted by the pump. To cope with the increase in irrigation water demand, this leads to an increase in pumped groundwater, and to prevent the groundwater from mining, the higher the treated wastewater injection rate into the groundwater zone required to compensate for the higher water demand by the system (Figure 10).

Table 8. Test the performance of the general conceptual model by perturbing porosity values, $\Phi$, while keeping all other variables constant.

\begin{tabular}{|c|c|c|c|c|c|c|c|c|}
\hline Run No. & $\begin{array}{l}\text { ET }_{c} \\
\text { (m/season) }\end{array}$ & $\begin{array}{l}\mathbf{E T}_{\mathbf{c}(\max )} \\
\text { (m/day) }\end{array}$ & $\begin{array}{l}\mathrm{C}_{\mathrm{RZ}} \\
(\mathrm{mg} / \mathrm{l})\end{array}$ & $\begin{array}{l}C_{\text {inj }} \\
(\mathrm{mg} / \mathrm{l})\end{array}$ & $\begin{array}{l}\Phi \\
\left(\mathrm{m}^{3} / \mathrm{m}^{3}\right)\end{array}$ & $\begin{array}{l}\text { K } \\
\text { (m/day) }\end{array}$ & $\begin{array}{l}\mathbf{h}_{\mathbf{o}} \\
(\mathbf{m})\end{array}$ & $\begin{array}{l}\left(\mathrm{C}_{\mathrm{g} . w .}\right)^{\mathrm{t}-1} \\
(\mathrm{mg} / \mathrm{l})\end{array}$ \\
\hline 1 & 1.50 & 0.015 & 2000 & 1000 & 0.30 & 5 & 35 & 6000 \\
\hline 2 & 1.50 & 0.015 & 2000 & 1000 & 0.35 & 5 & 35 & 6000 \\
\hline 3 & 1.50 & 0.015 & 2000 & 1000 & 0.40 & 5 & 35 & 6000 \\
\hline 4 & 1.50 & 0.015 & 2000 & 1000 & 0.45 & 5 & 35 & 6000 \\
\hline
\end{tabular}

Table 9. Percent increase in the sum of the total power consumption and the sum of the treated wastewater injection as the porosity increases.

\begin{tabular}{|c|c|c|c|c|}
\hline$\Phi$ Chan & To & $\begin{array}{l}\% \text { Change (increase) in } \\
\Phi\end{array}$ & $\begin{array}{l}\text { \% Change } \\
\text { (increase) in the Sum of } \\
\text { the Total Power per } \\
\text { Unit Area }\end{array}$ & $\begin{array}{l}\% \text { Change (increase) } \\
\text { in the Sum of the Injected Treated } \\
\text { Wastewater per Unit Area }\end{array}$ \\
\hline 0.30 & 0.35 & 14.29 & 0.94 & 0.03 \\
\hline 0.30 & 0.40 & 25.00 & 1.93 & 0.06 \\
\hline 0.30 & 0.45 & 33.33 & 2.83 & 0.09 \\
\hline
\end{tabular}

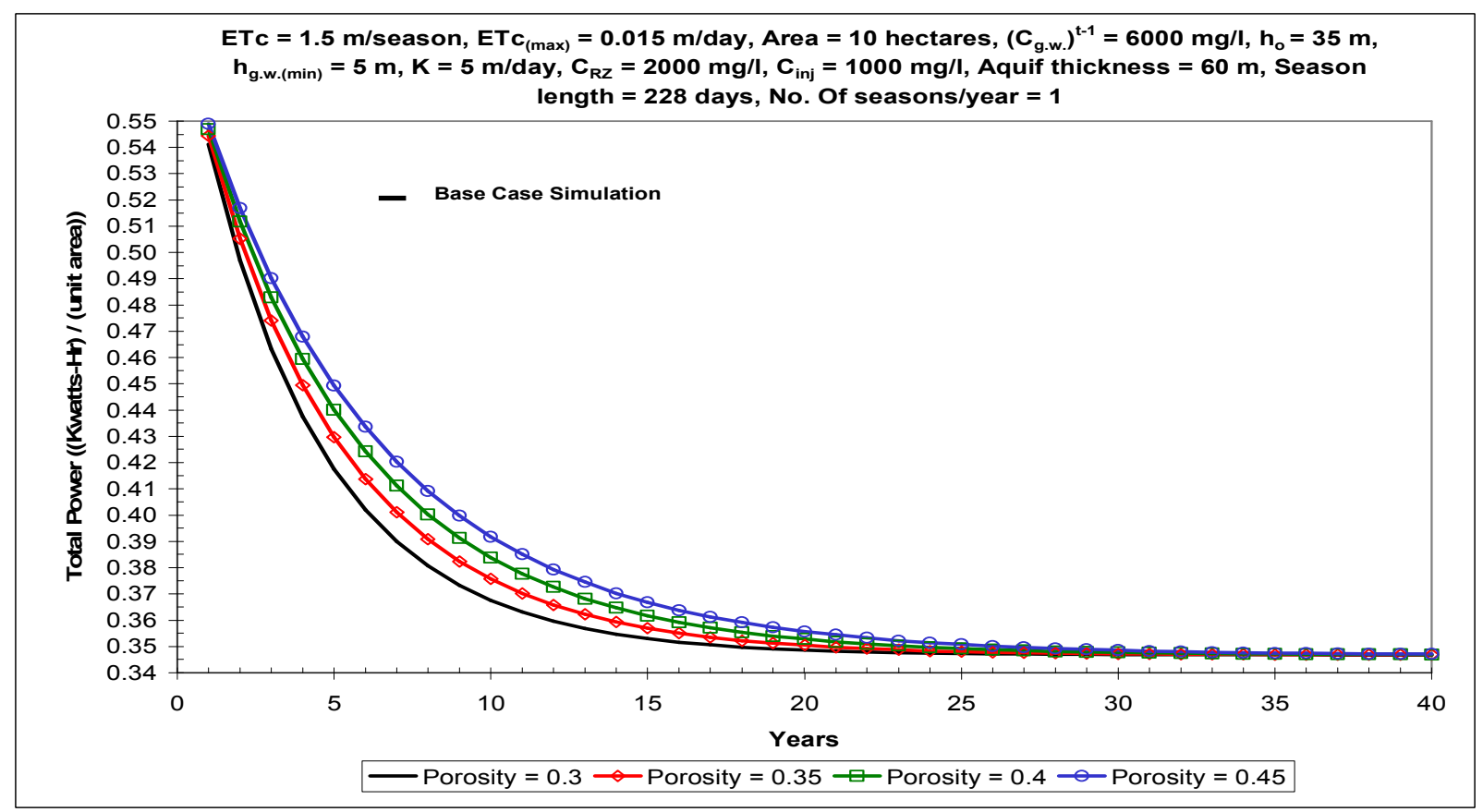

Figure 9. Total power required by the system for ranges of different porosity, $\Phi$,input values vs. simulation period. 


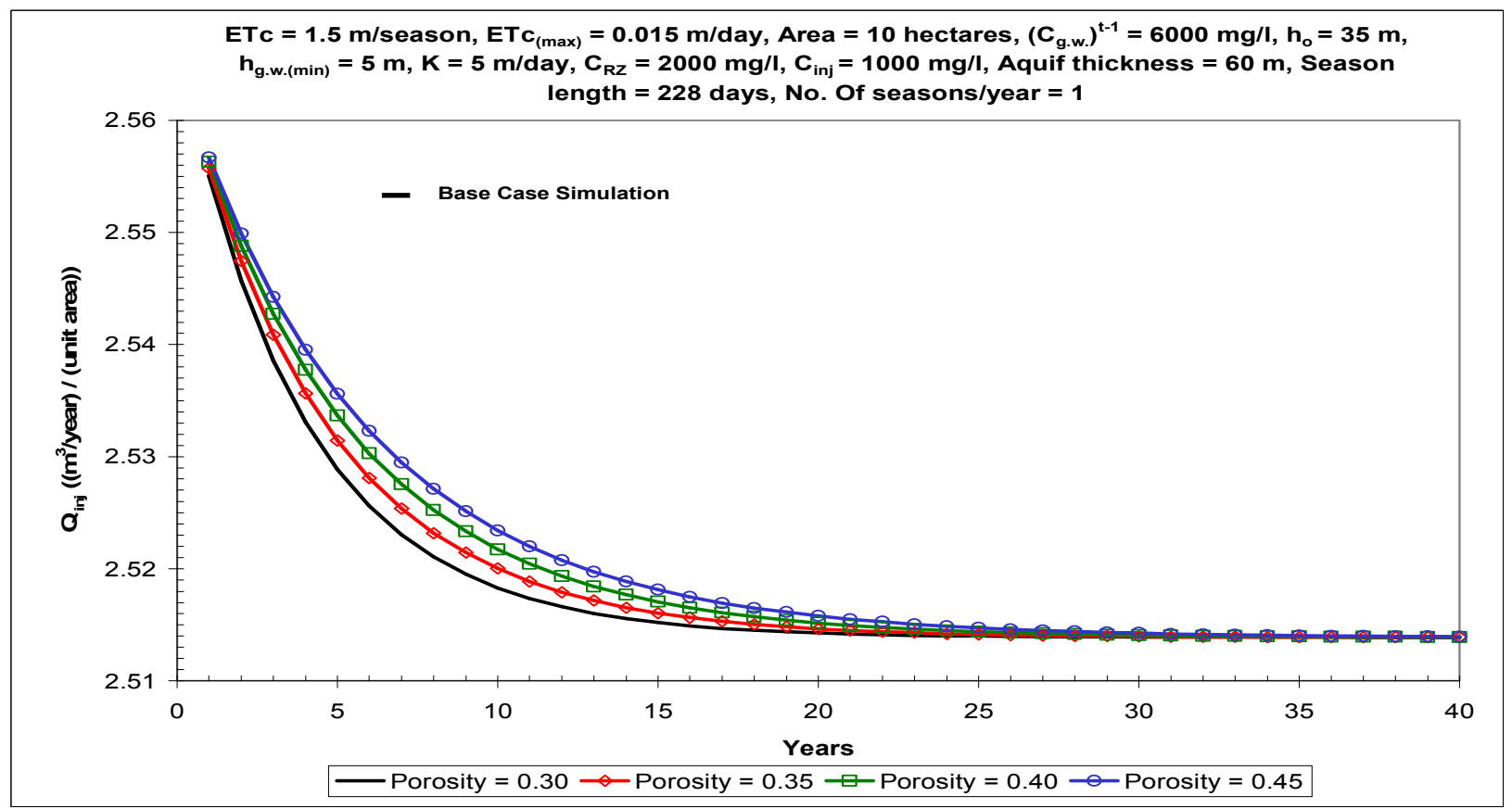

Figure 10. Amount of treated wastewater injected into the native groundwater for ranges of different porosity, $\Phi$, input values vs. simulation period.

\subsubsection{Hydraulic Conductivity, $K$}

Hydraulic conductivity, $K$, is of essential significance to groundwater variable input data in the simulation, as it measures the ease with which a fluid (water) can be transmitted in the porous media. Hydraulic conductivity data ranges $(3 \mathrm{~m} /$ day $-7 \mathrm{~m} /$ day $)$ were chosen to handle and distinguish the moderate hydraulic conductivity (i.e. $K=1$ $-10 \mathrm{~m} /$ day) of porous media (Table 10).

Results showed that as the hydraulic conductivity, $K$,increases the total power required by the system per unit area, and the amount of treated wastewater required to be injected into the groundwater zone per unit area does not change for ranges of hydraulic conductivity values. The hydraulic conductivity measures the ease with which a fluid (water) can be transmitted in the porous media. Thus, the higher the hydraulic conductivity of the soil matrix of the aquifer the more groundwater can be pumped from the groundwater zone. The higher the hydraulic conductivity the higher the amount of water that can be yielded from the aquifer for the same maximum allowed drawdown (minimum unconfined aquifer thickness). Therefore, due to this higher groundwater pumping yield capacity from the groundwater zone, a larger irrigated farm area can be utilized. Thus, higher crop yield can be produced which will lead to higher crop revenues. Although increase in hydraulic conductivity has no direct impact on the total power requirement by the system per unit area and on the injected treated wastewater amount into the groundwater per unit area, the higher the hydraulic conductivity the larger irrigated farm area can be utilized.

Table 10. Test the performance of the general conceptual model by perturbing hydraulic conductivity values, $K$, while keeping all other variables constant.

\begin{tabular}{|c|c|c|c|c|c|c|c|c|}
\hline Run No. & $\begin{array}{l}\mathbf{E T}_{\mathrm{c}} \\
\text { (m/season) }\end{array}$ & $\begin{array}{l}\mathbf{E T}_{\mathbf{c}(\max )} \\
\text { (m/day) }\end{array}$ & $\begin{array}{l}\mathrm{C}_{\mathrm{RZ}} \\
(\mathrm{mg} / \mathrm{l})\end{array}$ & $\begin{array}{l}\mathrm{C}_{\mathrm{inj}} \\
(\mathrm{mg} / \mathrm{l})\end{array}$ & $\begin{array}{l}\Phi \\
\left(\mathbf{m}^{3} / \mathbf{m}^{3}\right)\end{array}$ & $\begin{array}{l}\mathbf{K} \\
\text { (m/day) }\end{array}$ & $\begin{array}{l}\mathbf{h}_{\mathbf{0}} \\
(\mathbf{m})\end{array}$ & $\begin{array}{l}\left(\mathrm{C}_{\text {g.w. }}\right)^{t-} \\
(\mathrm{mg} / \mathrm{l})\end{array}$ \\
\hline 1 & 1.50 & 0.015 & 2000 & 1000 & 0.3 & 3 & 35 & 6000 \\
\hline 2 & 1.50 & 0.015 & 2000 & 1000 & 0.3 & 4 & 35 & 6000 \\
\hline $3 *$ & 1.50 & 0.015 & 2000 & 1000 & 0.3 & 5 & 35 & 6000 \\
\hline 4 & 1.50 & 0.015 & 2000 & 1000 & 0.3 & 6 & 35 & 6000 \\
\hline 5 & 1.50 & 0.015 & 2000 & 1000 & 0.3 & 7 & 35 & 6000 \\
\hline
\end{tabular}


Table 11. Percent change in the sum of the total power consumption, the sum of the treated wastewater injection, and farm area as the hydraulic conductivity increases.

\begin{tabular}{|c|c|c|c|c|c|}
\hline KChan & To & $\begin{array}{l}\% \text { Change (increase) } \\
\text { in } \\
K\end{array}$ & $\begin{array}{l}\text { \% Change } \\
\text { (increase) in the Sum of } \\
\text { the Total Power per Unit } \\
\text { Area }\end{array}$ & $\begin{array}{l}\% \text { Change (increase) } \\
\text { in the Sum of the Injected } \\
\text { Treated Wastewater per } \\
\text { Unit Area }\end{array}$ & $\begin{array}{l}\% \text { Change } \\
\text { (increase) in Farm } \\
\text { Area }\end{array}$ \\
\hline 3 & 5 & 33.33 & 0 & 0 & 40.00 \\
\hline 4 & 5 & 16.67 & 0 & 0 & 20.00 \\
\hline 5 & 6 & 14.29 & 0 & 0 & 16.67 \\
\hline 5 & 7 & 25.00 & 0 & 0 & 28.57 \\
\hline
\end{tabular}

\subsubsection{Initial Groundwater Table Hydraulic Head Elevation, ho}

Initial groundwater table hydraulic head elevation, $\boldsymbol{h}_{\boldsymbol{o}}$, is of vital importance to groundwater variable input data in the simulation, as it determines the amount of lift needed to be exerted by the well pump. Initial groundwater table hydraulic head elevation data ranges $(30 \mathrm{~m}-50 \mathrm{~m} /$ day $)$ were chosen to embody the average groundwater table elevation in most semi-arid and arid regions (Table 12).

From Figures 11 and 12, it is obvious that as the initial water table hydraulic head elevations increase the lower the total power per unit area required by the system and the higher the amount of treated wastewater per unit area required to be injected into the groundwater zone. As the initial water table hydraulic head elevations increase, the initial volume of groundwater will increase. Thus, the initial salt mass quantity of the groundwater will increase. Moreover, due to the larger initial groundwater volume, the enhancement of the salt concentration of the groundwater will be delayed compared with the lower initial water table hydraulic head

Table 12. Test the performance of the general conceptual model by perturbing initial groundwater table hydraulic head values, $h_{o}$, while keeping all other variables constant.

\begin{tabular}{|c|c|c|c|c|c|c|c|c|}
\hline Run No. & $\begin{array}{l}\mathbf{E T}_{\mathrm{c}} \\
\text { (m/season) }\end{array}$ & $\begin{array}{l}\mathbf{E T}_{\mathrm{c}(\max )} \\
(\mathbf{m} / \mathbf{d a y})\end{array}$ & $\begin{array}{l}\mathrm{C}_{\mathrm{RZ}} \\
(\mathrm{mg} / \mathrm{l})\end{array}$ & $\begin{array}{l}C_{\text {inj }} \\
(\mathrm{mg} / \mathrm{l})\end{array}$ & $\begin{array}{l}\Phi \\
\left(\mathrm{m}^{3} / \mathrm{m}^{3}\right)\end{array}$ & $\begin{array}{l}\text { K } \\
\text { (m/day) }\end{array}$ & $\begin{array}{l}\mathbf{h}_{\mathbf{0}} \\
(\mathrm{m})\end{array}$ & $\begin{array}{l}\left(C_{\text {g.w. }}\right)^{t-1} \\
(\mathrm{mg} / \mathrm{l})\end{array}$ \\
\hline 1 & 1.50 & 0.015 & 2000 & 1000 & 0.3 & 5 & 30 & 6000 \\
\hline 2 & 1.50 & 0.015 & 2000 & 1000 & 0.3 & 5 & 35 & 6000 \\
\hline 3 & 1.50 & 0.015 & 2000 & 1000 & 0.3 & 5 & 40 & 6000 \\
\hline 4 & 1.50 & 0.015 & 2000 & 1000 & 0.3 & 5 & 45 & 6000 \\
\hline 5 & 1.50 & 0.015 & 2000 & 1000 & 0.3 & 5 & 50 & 6000 \\
\hline
\end{tabular}

elevations (where the groundwater volume is less) as the simulation proceeds. Thus, the pumped groundwater initial salt concentration will be relatively higher as the initial groundwater volume increases due to the increase in initial water table hydraulic head elevations. Due to the increase in the pumped groundwater salt concentration, the feed water to the reverse osmosis unit will be at a relatively higher salt concentration. Hence, the water permeate from the reverse osmosis unit will be at a higher concentration, too. Therefore, the more permeate water required (to be used as irrigation water) to cope with the irrigation efficiency. Hence, irrigation water demand will increase to meet this increase in the initial water table hydraulic head elevations. Moreover, to meet this increase in the irrigation water demand, a larger groundwater amount must be pumped and fed to the reverse osmosisunit to cope with the irrigation water requirement increases. Therefore, the higher the pumped groundwater amount required to be fed to the reverse osmosis unit the higher the amount of water needed to be desalinated and the more power will be consumed by the reverse osmosis unit. In addition, due to the increase in the initial water table hydraulic head elevations, the height of water to be lifted by the pump to the ground surface will be reduced, thus reducing the amount of power to be exerted by the pump. However, the power consumed by the reverse osmosis unit will increase as the initial water table hydraulic head elevations; the height of water to be lifted by the pump to the ground surface will be reduced, thus reducing the amount of power to be exerted by the pump. However, the power consumed 
by the reverse osmosis unit will increase as the initialwater table hydraulic head elevations increase due to the increase in pumped groundwater salt concentration and the increase in the amount of the pumping water required. However, due to the pump power consumption reduction by reducing the left head, which is more dominant and influential, the total power exerted by the system will be reduced as the initial water table hydraulic head elevations increase. Thus, the total power of the system will be reduced. To cope with the increase in irrigation water demand, this leads to an increase in pumped groundwater, and to prevent the groundwater from mining, the higher the treated wastewater injection rate into the groundwater zone required to compensate for the higher water demand by the system. Moreover, the higher the initial water table hydraulic head elevation the higher the amount of groundwater can be pumped from the aquifer for the same maximum allowed drawdown (minimum unconfined aquifer thickness). Therefore, due to this higher groundwater pumping yield capacity from the groundwater zone, a larger irrigated farm area can be utilized.

\subsubsection{Initial Groundwater Salt Concentration, $\left(C_{g . w}\right)^{t-1}$}

Initial groundwater salt concentration of the native groundwater, $\left(C_{g . w}\right)^{t-1}$, is ofcrucial implication to groundwater variable input data in the simulation, as it determines the amount of distillation and power consumption needed to be exerted by the reverse osmosis unit. Initial groundwater salt concentration of the native groundwater data ranges $(4000 \mathrm{mg} / \mathrm{l}-12000 \mathrm{mg} / \mathrm{l})$ were chosen to represent brackish to brine groundwater quality, which is incompatible for direct crop irrigation in general (Table 14).

From Figures 13 and 14, it is obvious that as the initial groundwater salt concentration, $\left(C_{g . w}\right)^{t-1}$, increases the higher the total power required by the system, andthe higher the amount of treated wastewater required to be injected into the groundwater zone. As the initial groundwater, salt concentration increases the pumped groundwater salt concentration will be higher.

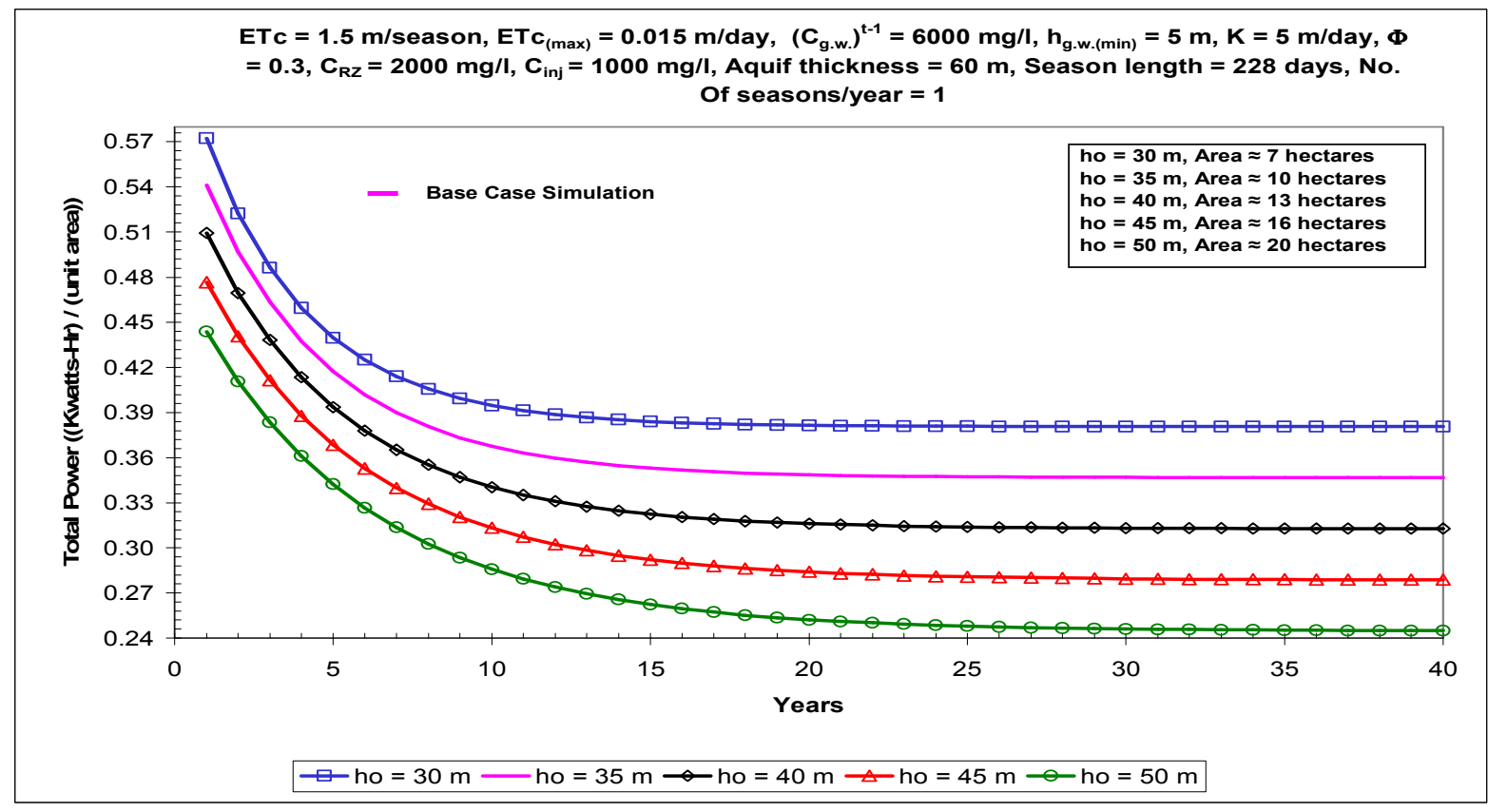

Figure 11. Total power required by the system for ranges of different initial water table hydraulic head elevations, $h_{o}$, input values vs. simulation period.

Table 13. Percent change in the sum of the total power consumption, the sum of the treated wastewater injection, and the farm area as the hydraulic initial water table hydraulic head elevation, $h_{o}$, increases.

\begin{tabular}{|c|c|c|c|c|c|}
\hline $\begin{array}{l}h_{o} \text { Cha } \\
\text { From }\end{array}$ & To & $\begin{array}{l}\% \text { Change (increase) } \\
\text { in } h_{o}\end{array}$ & $\begin{array}{l}\text { \% Change } \\
\text { (decrease) in the Sum of } \\
\text { the Total Power per Unit } \\
\text { Area }\end{array}$ & $\begin{array}{l}\text { \% Change (increase) } \\
\text { in the Sum of the } \\
\text { Injected } \\
\text { Wastewater per Unit } \\
\text { Area }\end{array}$ & $\begin{array}{l}\% \text { Change (increase) } \\
\text { in the Farm Area }\end{array}$ \\
\hline 30 & 35 & 14.29 & 7.70 & 0.03 & 27.08 \\
\hline 35 & 40 & 12.50 & 8.41 & 0.03 & 23.81 \\
\hline 35 & 45 & 22.22 & 16.81 & 0.05 & 40.00 \\
\hline 35 & 50 & 30.00 & 25.22 & 0.08 & 51.52 \\
\hline
\end{tabular}




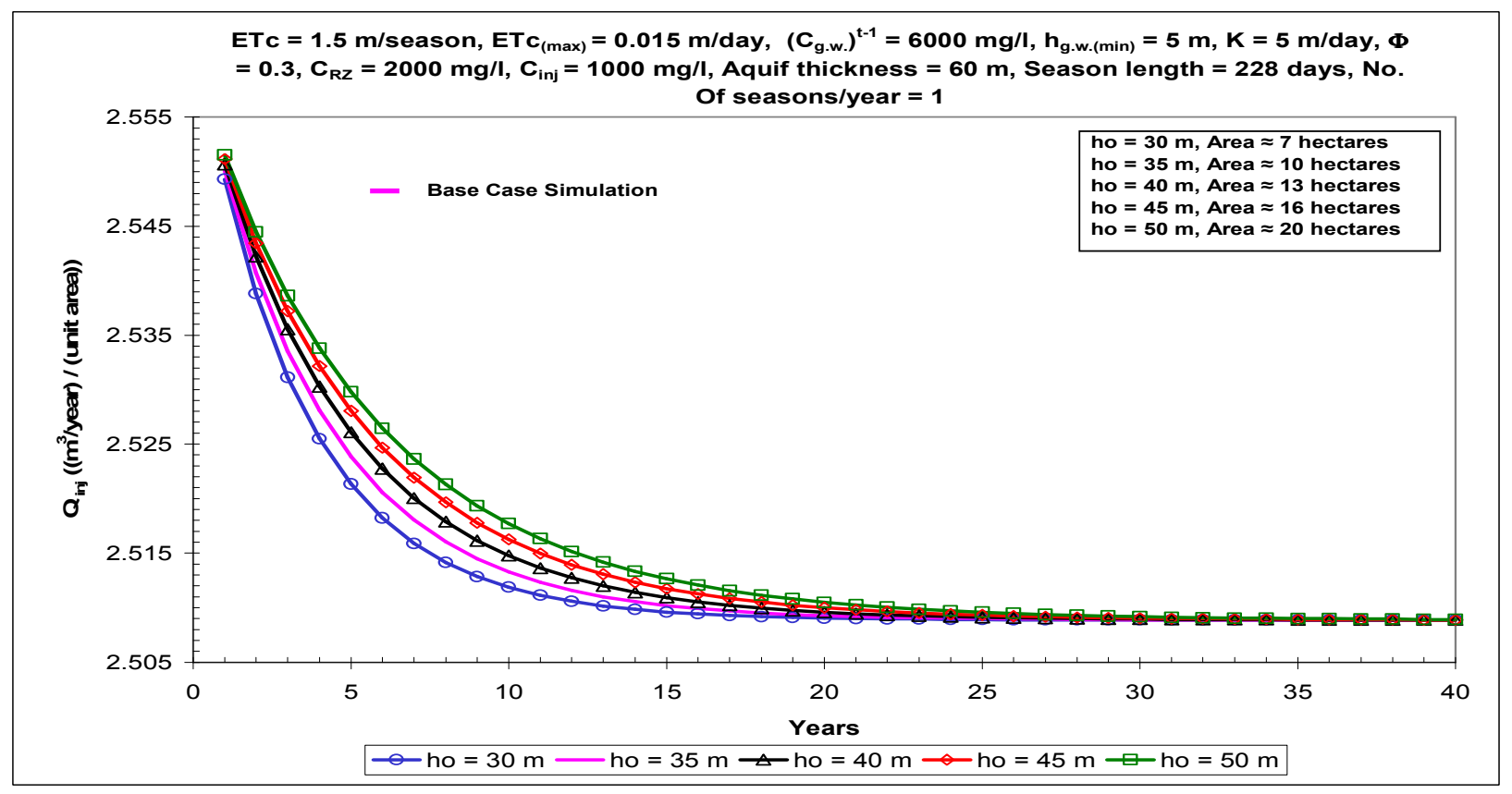

Figure 12. Amount of treated wastewater injected into the native groundwater for ranges of different initial water table hydraulic head elevations, $h_{o}$, input values vs. simulation period.

Due to the increase in the pumped groundwater salt concentration, the feed water to the reverse osmosis unit will be at a higher salt concentration. Thus, the water permeate from the reverse osmosis unit will be at a higher concentration, too. Therefore, the more permeate water required (to be used as irrigation water) to cope with the irrigation efficiency. Hence, irrigation water demand will increase to get by the increase in the groundwater salt concentration. Moreover, to meet this increase in the irrigation water demand, a larger groundwater amount must be pumped and fed to the reverse osmosis unit to cope with the irrigation water requirement increases. Therefore, the higher the pumped groundwater amount required to be fed to the reverse osmosis unit the higher the amount of water needed to be desalinated and the higher the power will be consumed by the reverse osmosis unit. In addition, the higher the pumped groundwater requirement the higher the power consumption will be used by the pump. To cope with the increase in irrigation water demand, this leads to an increase in pumped groundwater, and to prevent the groundwater from mining, the higher the treated wastewater injection rate into the groundwater zone required to compensate for the higher water demand by the system (Figure 14).

Table 14. Test the performance of the general conceptual model by perturbing initial groundwater salt concentration values, $\left(C_{g . w}\right)^{t-1}$, while keeping all other variables constant.

\begin{tabular}{|c|c|c|c|c|c|c|c|c|}
\hline Run No. & $\begin{array}{l}\mathbf{E T}_{\mathrm{c}} \\
\text { (m/season) }\end{array}$ & $\begin{array}{l}\mathbf{E T}_{\mathbf{c}(\max )} \\
(\mathbf{m} / \mathbf{d a y})\end{array}$ & $\begin{array}{l}\mathrm{C}_{\mathrm{RZ}} \\
(\mathrm{mg} / \mathrm{l})\end{array}$ & $\begin{array}{l}\mathrm{C}_{\mathrm{inj}} \\
(\mathrm{mg} / \mathrm{l})\end{array}$ & $\begin{array}{l}\Phi \\
\left(\mathrm{m}^{3} / \mathrm{m}^{3}\right)\end{array}$ & $\begin{array}{l}\text { K } \\
\text { (m/day) }\end{array}$ & $\begin{array}{l}h_{0} \\
(\mathbf{m})\end{array}$ & $\begin{array}{l}\left(\mathbf{C}_{\mathrm{g}, \mathrm{.w}}\right)^{\mathrm{t}-1} \\
(\mathbf{m g} / \mathbf{l})\end{array}$ \\
\hline 1 & 1.50 & 0.015 & 2000 & 1000 & 0.3 & 5 & 35 & 4000 \\
\hline 2 & 1.50 & 0.015 & 2000 & 1000 & 0.3 & 5 & 35 & 6000 \\
\hline 3 & 1.50 & 0.015 & 2000 & 1000 & 0.3 & 5 & 35 & 8000 \\
\hline 4 & 1.50 & 0.015 & 2000 & 1000 & 0.3 & 5 & 35 & 10000 \\
\hline 5 & 1.50 & 0.015 & 2000 & 1000 & 0.3 & 5 & 35 & 12000 \\
\hline
\end{tabular}




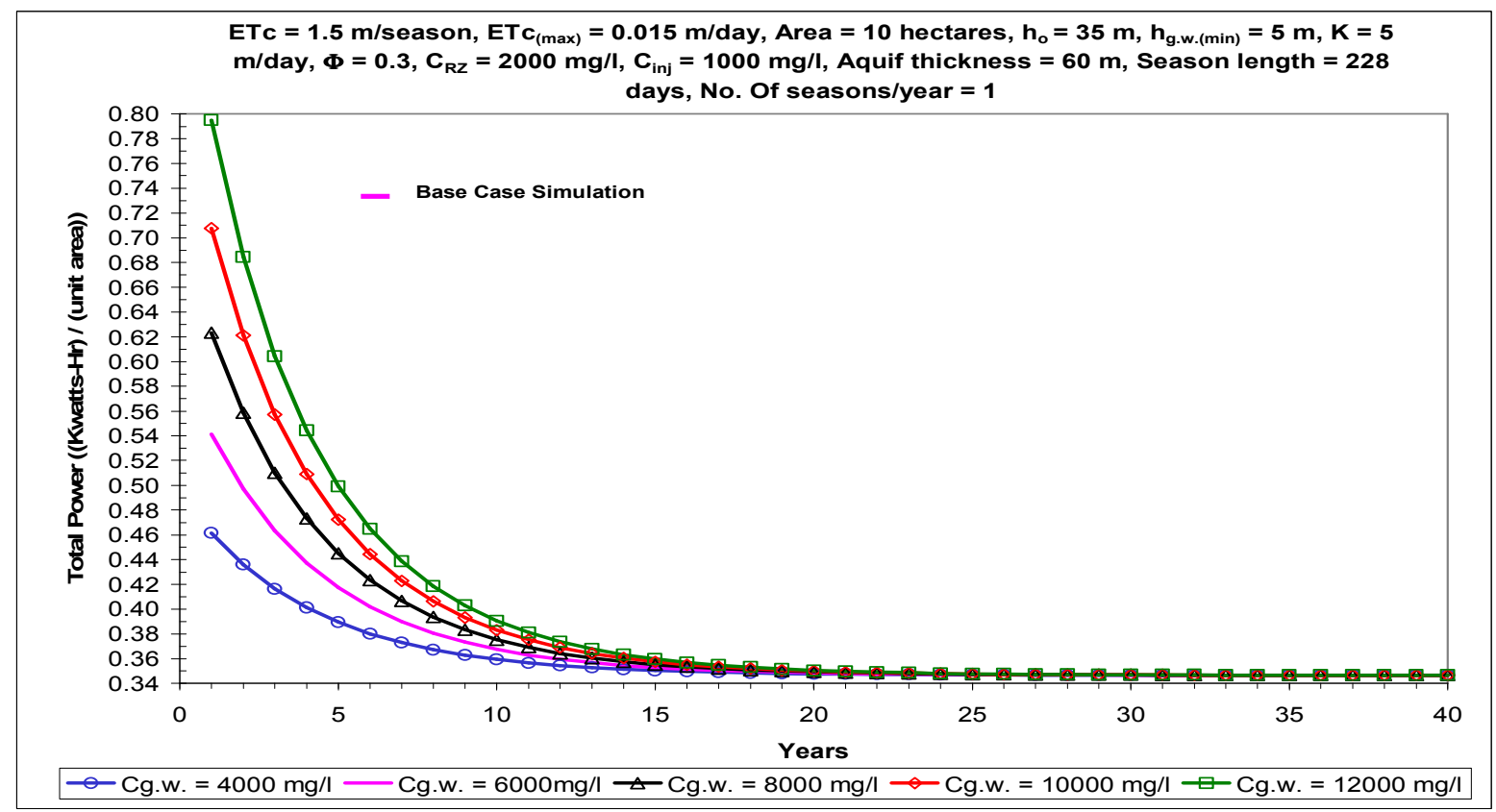

Figure 13. Total power required by the system for ranges of different initial groundwater salt concentrations, $\left(C_{g . w}\right)^{t-1}$, input values vs. simulation period.

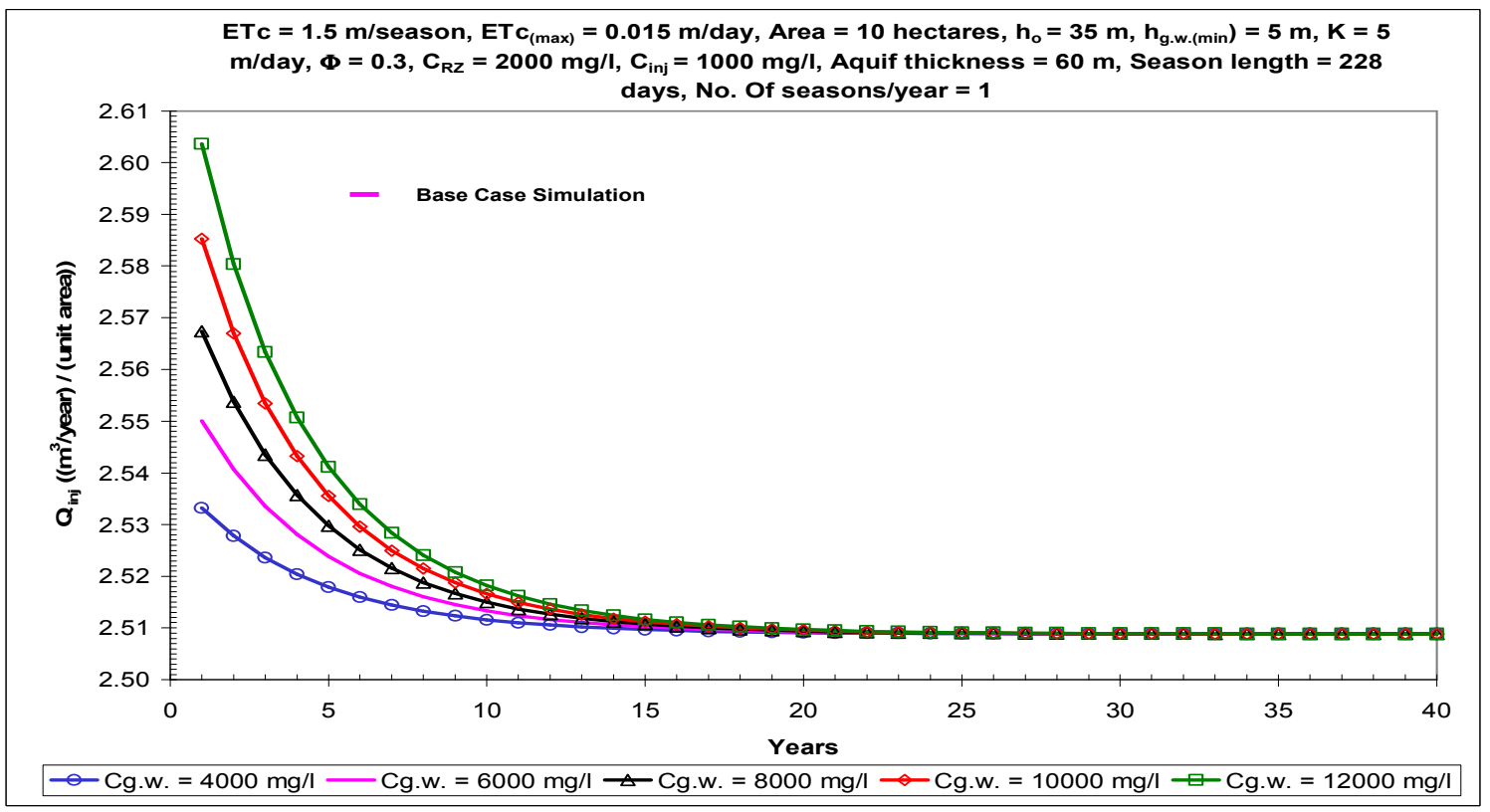

Figure 14. Amount of treated wastewater injected into the native groundwater for ranges of different initial groundwater salt concentrations, $\left(C_{g . w}\right)^{t-}$ ', input values vs. simulation period.

Table 15. Percent increase in the sum of the total power consumption and the sum of the treated wastewater injection as the hydraulic initial groundwater salt concentration, $\left(C_{\text {g.w. }}\right)^{t-1}$, increases.

\begin{tabular}{|c|c|c|c|c|}
\hline $\begin{array}{l}\left(C_{\text {g.w. }}\right)^{t} \\
\text { From }\end{array}$ & To & $\begin{array}{l}\text { \% Change (increase) in } \\
\left(C_{g . w .}\right)^{t-1}\end{array}$ & $\begin{array}{l}\text { \% Change } \\
\text { (increase) in the Sum of the } \\
\text { Total Powerper Unit Area }\end{array}$ & $\begin{array}{l}\% \text { Change (increase) } \\
\text { in the Sum of the Injected Treated } \\
\text { Wastewaterper Unit Area }\end{array}$ \\
\hline 4000 & 6000 & 33.33 & 2.44 & 0.07 \\
\hline 6000 & 8000 & 25.00 & 2.32 & 0.08 \\
\hline 6000 & 10000 & 40.00 & 4.53 & 0.15 \\
\hline 6000 & 12000 & 50.00 & 6.65 & 0.22 \\
\hline
\end{tabular}




\section{Conclusion}

From the performance test results, the increase in evapotranspiration had the highest increase effect on the system total power consumption per unit area and the highest increase effect on the treated wastewater consumption per unit area. On the other hand, the increase in the aquifer porosity had the least increase effect on both the total power consumption and the treated wastewater consumption by the system. In contrast, the hydraulic conductivity increase had no direct effect on either the total power consumption or on the treated wastewater consumption per unit area. The higher the hydraulic conductivity the higher the amount of water that can be yielded from the aquifer for the same maximum allowed drawdown (minimum unconfined aquifer thickness). Therefore, a larger irrigated farm area can be utilized, thus, higher crop yield can be produced. In addition, the higher the initial water table hydraulic head elevation the higher the amount of groundwater can be pumped from the aquifer for the same maximum allowed drawdown (minimum unconfined aquifer thickness). Therefore, a larger irrigated farm area can be utilized.

\section{References}

[1] Abdel-Jawad, M., Al-Shammari, S., and Al-Sulaimi, J. 2002. Non-ConventionalTreated Municipal Wastewater for Reverse Osmosis. Desalination Vol.142, pp. 11- 18.
[2] Allen, R. G., M. E. Jensen, J. L. Wright, and R. D. Burman. 1989. Operational estimates of evapotranspiration. Agron. J., 81:650-662.

[3] Al-Rashed, M., M. N. Al-Senafy, M. N. Viswanathan, and A. Sumait. 1998.Groundwater Utilization in Kuwait:Some Problems and Solutions. Water Resource Development, Vol 14, N0. 1, pp. 91-105.

[4] Al-Wazzan, Y., M. Safae, S. Ebrahim, N. Burney, and A. Mesri. 2002. Desalting of Surface Water Using SpiralWound Reverse Osmosis (RO) System: Technical and Economic Assessment. Desalination Vol. 142, pp. 21-28.

[5] MEW. 2000. Water Statistical Year Book. Ministry of Electricity and Water, Kuwait, 2000.

[6] MEW. 1989. Statistical Year Book, Water, ed. 16B, Ministry of Electricity and Water, Kuwait.

[7] Omar, S. A., I. El-Bagouri, Y. Anwar, F. Khalaf, M. Hashash, and A. Nassef. 1988. Measures to Control Mobile Sand in Kuwait. Vol. 1. Environmental Assessment and Control Measures, EES-78, Kuwait Institute for scientific research, Report No. KISR2760, Kuwait.

[8] Tanner, C. B. 1967. Measurement of evapotranspiration. 534-574. In Irrigation of Agricultural lands. Mono No. 11, Am. Soc. Agron., Madison, Wis.

[9] Thornthwaite, C. W. 1948. An approach toward a rational classification of climate. Geograph. Rev., 38, 55.

[10] Urila, L. 2002. Optimizing the Efficiency of Reverse Osmosis Seawater Desalination, http://urila.tripod.com/Seawater.htm, May (2002). 